\title{
From Service to Experience; understanding and defining the hospitality business
}

\author{
NIGEL HEMMINGTON
}

\begin{abstract}
Failure adequately to define or understand hospitality as a commercial phenomenon has created a fragmented academic environment and a schizophrenia in the industry that has the potential to limit its development as a global industry. This article suggests that, by redefining hospitality as behaviour and experience, a new perspective emerges that has exciting implications for the management of hospitality businesses. A framework to describe hospitality in the commercial domain is proposed. This framework suggests a focus on the host-guest relationship, generosity, theatre and performance, "lots of little surprises", and the security of strangers; a focus that provides guests with experiences that are personal, memorable and add value to their lives.
\end{abstract}

Key words: hospitality, experience, performance, theatre, surprise, service

Nigel Hemmington, School of Services Management, Bournemouth University, Fern Barrow, Poole BH12 5BB 


\section{From Service to Experience;}

\section{understanding and defining the hospitality business}

Failure adequately to define or understand hospitality as a commercial phenomenon has created a fragmented academic environment and a schizophrenia in the industry that has the potential to limit its development as a global industry. This article suggests that, by redefining hospitality as behaviour and experience, a new perspective emerges that has exciting implications for the management of hospitality businesses. A framework to describe hospitality in the commercial domain is proposed. This framework suggests a focus on the host-guest relationship, generosity, theatre and performance, "Iots of little surprises", and the security of strangers; a focus that provides guests with experiences that are personal, memorable and add value to their lives.

\section{INTRODUCTION}

The schizophrenia of the hospitality industry, and the "fragmentation" of hospitality academia (Jones 2004a), is a potentially limiting factor in the industry's drive for growth and development. This schizophrenia is illustrated 
by questions about whether the hospitality industry is a service industry, whether it is entertainment, or art, or theatre, or retailing, or whether it is no more than another form of business (Gillespie 1994, Jayawardena 2000, Slattery 2002, Hemmington 2004).

In the academic world, the dominant approach is one based on business and management, with many institutions focusing on services and some taking a retailing perspective. Jones (2002a) sought to identify the "principal schools of thought" and identified six main approaches: science, management, studies, relationships, systems, and pragmatism. However, as Morrison \& O'Mahoney (2002) state, there are "some major tensions, contradictions and debates confronting contemporary hospitality management educationalists", and that hospitality management as a field of study "continues to struggle for definition". This failure to understand the phenomenon of commercial hospitality acts a significant barrier to industry improvement (Wood 1992), customer satisfaction and therefore growth.

This conceptual article aims to explore and extend the debate surrounding hospitality in commercial environment. It seeks to do this by drawing on previous research, both empirical and conceptual, and charting a course between the divergent views of academics and practitioners, and by proposing a new framework that has strategic and operational implications for the hospitality industry. 


\section{DEFINING HOSPITALITY - THE DEBATE}

Hitherto, attempts to define commercial hospitality have tended to focus on the clustering and defining of groups of industrial activity (see for example Jones 1996). As Brotherton and Wood (2000) point out, this approach that has dominated the thinking of most academics and practitioners is one that takes a 'narrow, commercial, economic and industrial perspective' which leads to definitions that are 'highly circular and have limited utility.

In recent years, however, the debate has been stimulated by the work of Lashley \& Morrison (2000) who, in an edited work, present a range of different views of hospitality from the philosophical to the commercial, and include several interesting perspectives such as humour, the role of media and postmodernism. Perhaps the most significant contribution of this work is the exploration of the concept of hospitality in the three domains of the social, the private and the commercial environments. This led to a vigorous debate (Slattery 2002, Brotherton 2002, Slattery 2003, Brotherton 2003, Jones 2004b) with Slattery (2002) challenging what he characterises as the threedomain approach', and claiming that it excludes important aspects of the industry to the extent that 'it is portrayed as the poor relation' when compared with hospitality in the social and private domains. Indeed, Slattery (2002) is clear in his view that;

'Hotels, restaurants, bars and the other hospitality venues are 
businesses where the critical relationship is between sellers and buyers. The buyers are not guests, they are customers. The relationship is not philanthropic it is economic.'

Having criticised the 'three domainers' conception', Slattery presents his hospitality contexts model which structures the industry under four headings: Free-standing Hospitality Businesses, Hospitality in Leisure Venues, Hospitality in Travel Venues, and Subsidised Hospitality. Although this is an approach that harks back to the industrial classifications models mentioned earlier, it is interesting to note that the notion of hospitality contexts has similarities with the three domains approach; that is, both seek to define hospitality within the context of the environments within which it takes place. Whilst Lashley and Morrison (2000) look at the wider contexts of private, social, and commercial hospitality, Slattery (2002) focuses on the contextual sub-divisions of commercial hospitality.

It is unfortunate that despite having identified the weaknesses of extant definitions of hospitality, and presented an alternative three domains approach, the authors in Lashley and Morrison (2000) fail to explore the implications of hospitality in the social and private domain for the practice of hospitality in the commercial domain. Put simply, the question might be asked, how might commercial hospitality be made more hospitable?

In the same text, Brotherton and Wood (2000) offer a definition of hospitality: 
'A contemporaneous human exchange, which is voluntarily entered into, and designed to enhance the mutual well being of the parties concerned through the provision of accommodation, and/or food, and/or drink'

which, despite their claim that it 'captures the generic essence of hospitality', actually fails to capture any sense of the exciting, vibrant and creative industry in the real world. As Slattery (2002) states, this is a, 'denuded and sterile conception of commercial hospitality and hospitality management'.

In addition, the Brotherton and Wood (2000) definition highlights the preoccupation with the paraphernalia of hospitableness centred around food, drink and accommodation (Telfer 2000); and the provision of these through service. This has manifest itself in a preoccupation with customer service, service delivery and service quality. This is an approach that is dominated by the perspectives of supply and suppliers, it not one that customers recognise, it is not the language that customers use, and it is not an approach that reflects the consumer experience or demand perspective (Nailon 1982). The retention of a customer perspective is essential to the effective delivery of hospitality products; customers do not buy service delivery, they buy experiences; they do not buy service quality, they buy memories; they do not buy food and drink, they buy meal experiences. This was recognised as early as the 1960s when Campbell-Smith (1967) published his seminal work Marketing the Meal Experience, however, its true implications for the business have never been adequately explored. 
King's (1995) consideration of private hospitality and commercial hospitality domains predates Lashley and Morrison, and more significantly, extends the analysis to present a model of commercial hospitality. King (1995) then explores the implications of the "hospitality metaphor" for customer service organizations. These implications include understanding the guest, supporting host employees, generosity, managing social protocols, defining the type of hospitality relationship, and the importance of the human resource function. Braithwaite (2004) develops this approach in his paper on hospitality under "extreme circumstances" suggesting the additional dimension of identifying and enhancing the occasion, and reiterating the importance of generosity and memories.

As mentioned earlier, the limited academic debate has been dominated by the application of generic business and management theory. Indeed, as the orphans of the academic world, hospitality academics have perhaps jumped too readily into the world of services management, with little consideration for the true relevance and implications of this perspective for the concept of hospitality and the international hospitality industry. The assumption that the world of hospitality is analogous to services such as banking, finance and insurance is questionable, and intuitively hospitality would appear to be significantly different to these services. Indeed, consumer research that has sought to apply generic service sector models to hospitality, such as SERVQUAL, has found significant differences to the extent that new models have been developed with different dimensions of consumer satisfaction 
including DINESERV and LODGSERV (Knutson et al. 1989, Patton et al. 1994, Stevens et al. 1995).

\section{HOSPITALITY AS BEHAVIOUR AND EXPERIENCE}

In seeking a better definition and understanding of hospitality a more fruitful starting place might be a consideration of the nature of hospitableness; hospitality as behaviour and experience (O'Connor 2005). The Oxford English Dictionary (2002) defines hospitality as the 'friendly and generous reception of guests or strangers', while the Chambers English Dictionary (2001) defines it as, 'entertaining strangers and guests kindly and without reward: showing kindness: generous: bountiful'. As Lashley (2000) states, 'hospitality requires the guest to feel that the host is being hospitable through feelings of generosity, a desire to please and a genuine regard for the guest as an individual'.

Looking at hospitality in this way leads to consideration of concepts such as generosity, friendliness, the host-guest relationship, entertainment, and experiences given freely (King 1995). International and cross-cultural dimensions may also be interesting in this regard. However, defining hospitality like this highlights a number of interesting tensions between hospitableness and commercial hospitality. The most obvious being the tension between generosity and the economics of business. Indeed, it is this tension that raises the question of whether true hospitality can ever be provided within a commercial context (Lashley 2000, Telfer 2000). 
In order to explore the conceptual shift from service and services management to hospitality and experience management it is helpful to distinguish a number of key dimensions that characterise the differences between the perspectives. Pine and Gilmore (1999) sought to distinguish between services and what they call the 'experience economy' using a similar approach and some of their dimensions are helpful in the exploration of the differences between services and hospitality as discussed below and shown in figure 1. The critical difference between Pine and Gilmore's framework and figure 1 , however, is that figure 1 includes evidence, in the form of footnotes, to support the dimensions proposed.

\section{HOSTS AND GUESTS}

Laskley (2000) states that, 'hospitality is essentially a relationship based on hosts and guests' and it is the host-guest relationship that is the key distinguishing characteristic of hospitality from which several other dimensions emerge (Pritchard 1981, Stringer 1981). The notion of hosts and guests is fundamentally different to that of managers and customers and is much more socially and culturally defined. Darke \& Gurney (2000) explored the expectations and taboos of domestic hospitality, and identified a number of social rules, such as not complaining, that are clearly at variance with the commercial manager-customer relationship. The motives for the relationship are fundamental and Telfer (2000) identified categories of motives for social hospitality, including "other-regarding motives" and "reciprocal motives", that underpin the host-guest relationship. 
Figure 1: Hospitality from service to experience

\begin{tabular}{|c|c|c|}
\hline Dimensions & Service & Hospitality \\
\hline Who is it for? & Customers & Guests $^{1}$ \\
\hline Who manages it? & Manager & Host $^{1}$ \\
\hline How is it managed? & $\begin{array}{l}\text { Manufacturing } \\
\text { Commoditization }\end{array}$ & Theatre $^{2}$ \\
\hline $\begin{array}{l}\text { What is the economic } \\
\text { function? }\end{array}$ & Delivery & Staging $^{3}$ \\
\hline $\begin{array}{l}\text { What is the economic } \\
\text { relationship ? }\end{array}$ & Parsimony & Generosity $^{4}$ \\
\hline Who delivers it? & Staff & Cast $^{5}$ \\
\hline What is the delivery goal ? & Customer Service & Performance $^{5}$ \\
\hline What is the timing? & Delivered on demand & Lots of little surprises ${ }^{6}$ \\
\hline What are the needs? & Functional & Experiential $^{7}$ \\
\hline Who leads? & Customer led & Host led ${ }^{8}$ \\
\hline $\begin{array}{l}\text { What is the nature of } \\
\text { the offering ? }\end{array}$ & Intangible & Memorable $^{9}$ \\
\hline $\begin{array}{l}\text { What are the factors of } \\
\text { demand? }\end{array}$ & Benefits & Sensations $^{9}$ \\
\hline $\begin{array}{l}\text { What are the security } \\
\text { concerns? }\end{array}$ & of goods and processes & of strangers ${ }^{10}$ \\
\hline \multicolumn{3}{|c|}{$\begin{array}{l}{ }^{1} \text { Lashley 2000, King 1995, Pritchard 1981, Stringer 1981, Telfer 2000, } \\
\text { Darke and Gurney 2000. } \\
\text { 2 Jayawardena 2000, Gillespie } 1994 . \\
{ }^{3} \text { Pine and Gilmore 1999, Jayawardena } 2000 \\
{ }^{4} \text { King 1995, Braitwaite 2004, Hemmington 2004, O’Connor } 2004 \\
{ }^{5} \text { Gillespie 1994, Darke and Gurney 2000, Jayawardena 2000, Winsted 2000, } \\
\text { Kivela et al. 2000. } \\
{ }^{6} \text { Pine and Gilmore 1999, Hemmington } 2004 \\
{ }^{7} \text { Campbell-Smith 1967, Gillespie 1994, Hansen et al. 2004. } \\
{ }^{8} \text { Gillespie 1994, Hemmington } 2004 \\
{ }^{10} \text { Braithwaite 2004, Pine and Gilmore } 1999 \\
\text { Lepple et al. 1990, King 1995, Telfer 2000, Rutherford and McConnell 1991, Poon and } \\
\text { Low, Gill et al. 2002, Choi and Chu 2000. }\end{array}$} \\
\hline
\end{tabular}




\section{GENEROSITY}

A discussion of the motives of hospitality leads back to a consideration of the tension between generosity and the economic relationship in commercial hospitality environments (King 1995). The need to control costs and generate a financial return is the economic reality of hospitality business, but is not one that normally applies to hospitality in social environments. This leads to several tensions when businesses attempt to provide a true sense of hospitality, for example, requiring guests constantly to sign for products acts as an on-going reminder of the economic relationship (O'Connor 2004), charging for minor elements of the product (e.g. butter, sauces) that could be included as part of the whole, and the overt practice of portion control which gives the impression of meanness. These practices are the antithesis of true hospitality and indeed, some hospitality businesses allow these financial controls to dominate the guest experience to a level where they appear parsimonious and unfriendly. Accepting that businesses have to make a financial return, the challenge would seem to be one of distancing the guest experience from necessary internal financial controls, and removing or redesigning unnecessary controls. A good example of this is the "all-inclusive" format where the financial aspect of the relationship is dealt with once, and usually before the experience. This then enables the hospitality experience to develop without reminders of the economic relationship and for a sense or generosity to be developed. Other opportunities to create a sense of generosity should also be explored; these might include the "bottomless cup of coffee", the "honesty bar", and other low cost additions to the experience. 
The key in all of this is to factor in the cost (and profit margin) of these elements into the overall price charged for the experience (Hemmington 2004).

\section{THEATRE AND PERFORMANCE}

The focus on experience and performance suggests an interesting analogy with theatre. In both hospitality and theatre there is a need to stage-manage experiences and a sense of staging the environment. In both hotels and restaurants the preparation of the front of house as the stage, takes time, it has to be meticulous, and is critical to the experience (Jayawardena 2000). The laying of tables, the folding of napkins, the arrangement of decorations such as flowers, the lighting, and the sound are all part of the stage management of the restaurant and preparation for the subsequent performance. Indeed, there are aspects of hospitality that are more experiential than theatre - restaurants have opportunities to stimulate all five senses, for example, and most hospitality experiences are individual and personalised rather than batch delivery as they are for a theatre audience.

The notion of performance is significant both in terms of the guest experience and the implications for staff as performers (Darke and Gurney 2000). If performance is an important aspect of the experience, which Winsted's (2000) research indicates it is, organizations should explore the opportunities to enhance the levels of performance. Staff, as the cast who provide the 
performance, need to be selected and developed as performers and need to be provided with the opportunities to perform. This is not necessarily about juggling and telling jokes, but could be about presenting and describing the menu in an effective way, acting as a gastronomic consultant (Kivela et al. 2000), serving the dishes with style, and could include elements of preparation at the table - perhaps even gueridon service. It is interesting to note that in recent years most of the performance in restaurants has been withdrawn into the kitchen with the chefs leaving the restaurant staff with limited opportunities to perform.

\section{“LOTS OF LITTLE SURPRISES"}

In services, much play is made of the fact that services have to be delivered on demand and that the product and customer have to be brought together at critical moments in time. In experiences, such as hospitality, this concept is extended by the fact that the performance and experience is revealed over time (Pine and Gilmore 1999). This has interesting operational implications. The hospitality experience could take place over a couple of hours for a meal, days for a short hotel visit and weeks for an extended vacation. In all of these, however, it should be recognised that the experience is not delivered in one moment in time, but is revealed over time, and over an extended period of time in some cases. This means that operators need to reveal the experience and the performance over time; they need to maintain interest and excitement over the whole period of the experience. This might be 
characterised as revealing "lots of little surprises". Restaurants are quite good at this; they offer canapés and other gastronomic temptations before the meal; they reveal each course one by one, sometimes from under cloches to add to the dramatic effect; they create interesting and unusual ways to serve and present the food; and they conclude with chocolates or mints or petit fours. In a recent restaurant review Moir (2005) characterised the experience at one restaurant as 'a chain of sparking moments that blaze together into a dazzling whole'. Hospitality businesses should design their guest experiences to include 'lots of little surprises', or 'sparkling moments', much as good restaurants do, using the ideas and creativity of their staff to stimulate and excite their guests over time.

The concept of surprise leads to another key dimension of hospitality. The extent to which the experience should be customer led or host led. Market orientation dictates that consumer products should be consumer led and that organizations should respond to the needs of the customer. However, if the intention is to create guest surprise, the creative ideas for the surprise are unlikely to come from the guests themselves. Indeed, going back to hospitality in the social context, it would be quite inappropriate for guests to dictate their requirements to their host, or to treat their host as a servant. In commercial hospitality the same principle should apply and this might help remove the confusion between service and servile; staff are performers and hosts, not servants. In truly hospitable environments guests are looking for something special that gives surprise and delight. This means that the innovations are more likely to be host led and will depend upon the creativity of the host and 
the staff as performers. It means that they have to interpret the needs of their guests in unusual and exciting ways that create memorable experiences; experiences that encourage guests to return (behavioural loyalty) and that guests will be sufficiently excited about to discuss with their friends creating positive word of mouth promotion (emotional loyalty).

\section{SECURITY OF STRANGERS}

The final, but significant, dimension of hospitality relates to the security of strangers. Telfer (2000) points out that "traditionally the most important responsibility of all was the guest's safety - hospitality was a kind of sanctuary". This is an aspect that is often overlooked and is perhaps insufficiently recognized by the industry. Hospitality guests, particularly hotel guests are often in unfamiliar and alien environments and see the hotel as an important sanctuary (Hepple et al. 1990, Rutherford and McConnell 1991, King 1995, Telfer 2000, Choi and Chu 2000, Gill et al. 2002, Poon and Low 2005). In most service industries, however, the dominant security concerns relate to the security of goods and procedures, this is also the case in some hospitality organizations, this leads to a focus on control procedures and financial control issues dominating the hospitality experience as discussed earlier in the article. Security in hospitality should, therefore, focus on guest security - the security of strangers. This does not mean that financial security should be ignored, but that from the guest's perspective their personal 
security is clearly visible and seen as the dominant concern rather than the security of the hotel's resources and procedures.

\section{CONCLUSION}

To conclude, this article has sought to chart a course through contemporary discourse, and between the theoretical and practical, to identify the strategic and operational implications of hospitality in commercial environments. It suggests that by exploring and defining hospitality as experience, new perspectives emerge that have important implications for hospitality in commercial contexts. These implications take hospitality beyond services management to a place where hospitableness, a sense of theatre and generosity are central.

Five key dimensions of hospitality as a commercial experience are identified; the host-guest relationship, generosity, theatre and performance, lots of little surprises and safety and security. To conclude, hospitality businesses must focus on the guest experience and stage memorable experiences that stimulate all five senses. They must behave like hosts taking responsibility for the experience and creating lots of little surprises. They must appoint and develop their staff as performers and the cast in the experience. They must create a feeling of generosity, avoid parsimony, and not allow financial and operational control procedures to dominate the guest experience. Hospitality organisations that are able to capture this sense of theatre and generosity will 
gain competitive advantage by providing their guests with experiences that are personal, memorable and add value to their lives.

\section{References}

Braitwaite, R.W. (2004), Five Meals in the Forties: Perspectives on hospitality under extreme circumstances, Tourism Review International, Vo.7, pp61-66.

Brotherton, B. (1999), Towards a definitive view of the nature of hospitality and hospitality management, International Journal of Hospitality Management, Vol.11 No.4, pp163-173.

Brotherton, B. and Wood, R. (2000), Hospitality and hospitality management, in Lashley \& Morrison, In Search of Hospitality, Butterworth Heinemann.

Brotherton, B. (2002), Finding the hospitality industry (A Response to Paul Slattery), Journal of Hospitality, Leisure, Sport \& Tourism Education, Vol.1 No.2, http://www.hlst.heacademy.ac.uk/johlste/vol1no2/comments/0032.html

Brotherton, B. (2003), Finding the hospitality industry (A Final Response to Slattery?), Journal of Hospitality, Leisure, Sport \& Tourism Education, Vol.2 No.2, http://www.hlst.heacademy.ac.uk/johlste/vol2no2/comments/0056.html

Campbell-Smith, G. (1967), Marketing the Meal Experience, University of Surrey, Guildford.

Choi, T.Y. and Chu, R. (2000), Levels of satisfaction among Asian and Western Travellers, International Journal of Quality \& Reliability Management, Vol.17 No.2, pp116-132.

Darke, J. \& Gurney, C. (2000), Putting up ? Gender, hospitality and performance, in Lashley \& Morrison, In Search of Hospitality, Butterworth Heinemann.

Erdly, M. and Kesterson-Townes, L. (2002), Experience Rules, IBM Business Consulting Services' Vision for the hospitality and leisure industry, circa 2010, IBM Business Consulting Services.

Gill, M., Moon, C., Seaman, P. and Turbin, V. (2002), Security management and crime in hotels, International Journal of Contemporary Hospitality Management, Vol.14 No.2, pp58-64.

Gillespie, C.H. (1994), Gastrophy and Nouvelle Cuisine: Entrepreneurial Fashion and Fiction, British Food Journal, Vol.96 No.10, pp19-23.

Hansen, K.V., Jensen, O. and Gustafsson, I., (2004) Payment - an undervalued part of the meal experience?, Food Service Technology, Vol.4 No.2, pp85-91.

Harris, W.T. (1996), Captive Audiences and the Price of Popcorn, Pennsylvania Economic Review, Vol. 5, No. 2, 1996.

Harris, R., Harris, K \& Baron, S (2003), Theatrical service experiences, International Journal of Service Industry Management, Vol.14 No.2, pp184-199. 
Heal, F. (1990), Hospitality in early modern England, Oxford University Press, Oxford.

Hemmington, N (2004), Concepts of Hospitality - from service to experience, Proceedings I-CHRIE Conference, Philadelphia, July 2004.

Hepple,J., Kipps, M. and Thomson, J. (1990), The concept of hospitality and an evaluation of its applicability to the experience of hospital patients, International Journal of Hospitality Management, Vol.9 No. 4, pp305317.

Jayawardena, C. (2000), International Hotel Manager, International Journal of Contemporary Hospitality Management, Vol.12 No.1, pp67-69.

Jensen, R. (1999), The Dream Society, McGraw-Hill.

Jones, P. (1996), Introduction to Hospitality Operations, Cassell, London. Jones, P. (2004a), Finding the Hospitality Industry? Or finding Hospitality Schools of Thought? Journal of Hospitality, Leisure, Sport \& Tourism Education, Vol.3 No.1, http://www.hlst.heacademy.ac.uk/johlste/vol3no1/comments/0069.html

Jones, P. (2004b), Finding the Hospitality Industry: A Response to Brotherton and Slattery, Journal of Hospitality, Leisure, Sport \& Tourism Education, Vol.3 No.1, http://www.hlst.heacademy.ac.uk/johlste/vol3no1/comments/0069.html

King, C.A. (1995), What is hospitality? International Journal of Hospitality Management, Vol.14 No. 3\&4, pp219-234.

Kivela, J., Inbakaran, R. and Reece, J. (2000), Consumer research in the restaurant environment. Part 3: analysis, findings and conclusions, International Journal of Contemporary Hospitality Management, Vol.12 No.1, pp13-30.

Knutson, B., Stevens, P., Wullaert, C., Patton, M., and Yokoyama, F. (1989), The Service Scoreboard: A Service Quality Measurement Tool for the Hospitality Industry, Hospitality Education and Research Journal, Vol.14 No.2, pp413-420.

Lashley, C. (2000), Towards a theoretical understanding, in Lashley \& Morrison, In Search of Hospitality, Butterworth Heinemann, pp1-17.

Lashley, C. \& Morrison, A. (2000), In Search of Hospitality; Theoretical perspectives and debates, Butterworth-Heinemann, Oxford.

Moir, J. (2005), "Are you ready to order?", Telegraph Weekend, December 31 , p20.

Morrison,A. \& O'Mahoney, G.B. (2002), Hospitality: A Liberal Introduction, Journal of Hospitality and Tourism Management, Vol. 9 No.2, pp189197.

Nailon, P. (1982), Theory in hospitality management, International Journal of Hospitality Management, Vol.1 No.3, pp135-142.

Nijs, D. (2003), Imagineering: Engineering for imagination in the emotion economy, in Creating a Fascinating World, Breda University, Holland.

O'Connor, D. (2005), Towards a new interpretation of hospitality, International Journal of Contemporary Hospitality Management, Vol.17 No.3, pp267271.

Patton, M., Stevens, P. and Knutson, B. (1994), Internationalizing LODGESERV as a Measurement Tool: A Pilot Study, Journal of Hospitality and Leisure Marketing, Vol.2 No.2, pp39-56. 
Pine, B.J. and Gilmore, J.H. (1998), Welcome to the experience economy, Harvard Business Review, July-August, pp97-105.

Pine, B.J. and Gilmore, J.H. (1999), The Experience Economy, HBS Press.

Poon, Wai-Ching and Low, K.L. (2005), Are travelers satisfied with Malaysian hotels ?, International Journal of Contemporary Hospitality Management, Vol.17 No.3, pp217-227.

Pritchard, M. (1981), Guests and Hosts, Oxford University Press, Oxford.

Rutherford, D.J. and McConnell, J.P. (1991), De Facto Security Standards: Operators at Risk, The Cornell HRA Quarterly, February, pp106-117.

Shortt, G. and Ruys, H. (1994), Hotel Security: The needs of the Mature Age Market, International Journal of Contemporary Hospitality Management, Vol.6 No.5, pp14-19.

Slattery, P. (2002), Finding the hospitality industry, Journal of Hospitality, Leisure, Sport \& Tourism Education, Vol.1 No.1, http://www.hlst.heacademy.ac.uk/johlste/vol1no1/academic/0007.html

Slattery, P. (2003), Finding the hospitality industry (Slattery's reply to Brotherton), Journal of Hospitality, Leisure, Sport \& Tourism Education, Vol.2 No.1, http://www.hlst.heacademy.ac.uk/johlste/vol2no1/comments/0040.html

Stevens, P., Knutson, B., and Patton, M. (1995), DINESERV: A Tool for Measuring Service Quality in Restaurants, Cornell Hotel and Restaurant Administration Quarterly, Vol.36 No.2, pp56-60.

Stringer, P.F. (1981), Hosts and Guests; The bed and breakfast phenomenon, Annals of Tourism Research, vol.8 no.3, pp357-376.

Telfer, E. (2000), The philosophy of hospitableness, in Lashley \& Morrison, In Search of Hospitality, Butterworth Heinemann.

Visser (1991), The Rituals of Dinner, HarperCollins.

Winsted, K.F. (2000), Service behaviours that lead to satisfied customers, European Journal of Marketing, Viol.34 No.3/4, pp399-417.

Wood, R. (1995), The Sociology of the Meal, Edinburgh University Press.

Wood, R. (1992), Working in hotels and catering, Routledge. 